\title{
Benthic macroinvertebrates in Italian rice fields
}

\author{
Daniela LUPI, ${ }^{*}$ Anna ROCCO, Bruno ROSSARO
}

University of Milan, Department of Food, Environmental and Nutritional Sciences (DeFENS), Via Celoria 2, 20133 Milano, Italy.

*Corresponding author: daniela.lupi@unimi.it

\section{ABSTRACT}

Rice fields can be considered man-managed temporary wetlands. Five rice fields handled with different management strategies, their adjacent channels, and a spring were analysed by their benthic macroinvertebrate community to i) evaluate the role of rice agroecosystem in biodiversity conservation; ii) find indicator species which can be used to compare the ecological status of natural wetlands with rice agroecosystems; and iii) find the influence of environmental variables on biodiversity. Different methods of data analysis with increasing degree of complexity - from diversity index up to sophisticated multivariate analysis - were used. The investigation provided a picture of benthic macroinvertebrates inhabiting rice agroecosystems where 173 taxa were identified, 89 of which detected in rice paddies. Among them, 4 phyla (Mollusca, Annelida, Nematomorpha, and Arthropoda), 8 classes (Bivalvia, Gastropoda, Oligochaeta, Hirudinea, Gordioida, Insecta, Branchiopoda, and Malacostraca), 24 orders, 68 families, 127 genera and 159 species have been found. Ten threatened and 3 invasive species were detected in the habitats examined. The information obtained by the different methods of data analysis allowed a more comprehensive view on the value of the components of rice agroecosystems. Data analyses highlighted significant differences between habitats (feeding channel and rice field), with higher diversity observed in channels, and emphasised the role of the water chemical-physical parameters. The period of water permanence in rice fields resulted to be only one of the factors influencing the community of benthic macroinvertebrates. The presence of rarelendangered species allowed characterising some stations, but it was less informative about management strategies in rice paddies because most of these species were absent in rice fields.

Key words: biodiversity indices, faunistic composition, water parameters, wetlands, rice fields, self-organising map.

Received: August 2012. Accepted: November 2012.

\section{INTRODUCTION}

Wetlands are habitats suitable for many species of benthic macroinvertebrates (Biggs et al., 1994). The communities are influenced by many environmental factors; the surrounding landscape and the duration of flood are of special importance, allowing the maintenance of a welldiversified fauna (Minelli, 2001; Della Bella et al., 2005). In the past, Northern Italy was characterised by large alluvial areas, but at present, the development of densely colonised, industrialised, and cultivated areas has strongly reduced the presence of natural temporary ponds (Fasola, 2003; Stoch, 2005). In this context, the widespread occurrence of rice agroecosystem in the Po river basin could surrogate the loss of natural wetlands (Lawler, 2001; Angelini et al., 2008) and could be evaluated as a hot spot of diversity in a highly impacted plain. Moreover, we must consider that rice paddies are not isolated but they are connected by channels, which could be of particular interest in supporting and enhancing rice field biodiversity.

Rice agroecosystem is subject to different anthropogenic effects that can vary significantly within the country and can have effect on macroinvertebrate composition. They are principally due to the source and the regularity of water supply, soil permeability and different environmental factors (Moormann and van Breemen,
1978). It must not be overlooked that the natural water cycle in rice fields is strongly altered because paddies are flooded during the rice growing period and dries up in autumn and winter, while natural ponds are generally richer in water during colder seasons. The absence of water in rice field in this period is unfavourable to the development of many species which overwinter in the preimaginal stage in wetlands (Suhling et al., 2000). Besides, one must consider that the flooding period is strongly influenced by management techniques (e.g. seeding technique or water removal to allow operations such as weed and eventually insecticide treatments). The shortage of the period of water permanence can affect the survival of species with longer cycle (Bazzanti et al., 2003; Caramujo and Boavida, 2010). Water in rice fields is also subject to quick physical and chemical changes (Panizzon et al., 2012). Thermal fluctuations are directly affected by the height of rice plants, with the consequent creation of a microclimate with aspects of tropical and subtropical areas with small thermal excursions also at northern latitude (Confalonieri et al., 2005). Al-Shami et al. (2010) reported the influence of agronomic practices on dissolved oxygen, $\mathrm{pH}$, conductivity, phosphate and nitrate. As a result, the rice agroecosystem is a very complex environment and all small modifications can have direct effects on macroinvertebrate communities. 
One must consider that Italian literature on macroinvertebrate community in rice fields is richer on rice pests than on the overall biodiversity. Furthermore, most papers are now outdated (Supino, 1932; Moroni, 1961) and remarkable information is restricted to some aquatic insects [Del Guercio (1911), Cavazza (1914), Supino (1916), Moretti (1932, 1934), Goidanich (1939), Zangheri (1956), Moroni (1961), Cocchi (1966), Corbetta (1973), Ferrarese (1992), Pasini and Ferrarese (1998), Bellini et al. (2000), and Caldara (2004)]. Apart from information on macroinvertebrates, an insight into other components of rice field communities is available (e.g. Ostracoda) (Rossi et al., 2003).

The principal aim of this work is to evaluate the role of rice agroecosystem in biodiversity conservation in Northern Italy, also considering the effect of different management practices on the benthic macroinvertebrate communities. Different methods of data analysis with increasing degree of complexity - from simple Shannon diversity index up to sophisticated unsupervised neural networks and between-class co-inertia analysis (BCA) - are used to test how the different components of the community are affected. The role of management techniques and water chemistry on agroecosystem functioning will be evaluated emphasising the relation among environmental factors and species richness. This investigation will also provide a more comprehensive picture of benthic macroinvertebrates inhabiting rice agroecosystems with a detailed taxonomic study.

\section{METHODS}

\section{Study area}

Benthic macroinvertebrates were sampled between June 2009 and March 2011 in six different stations in Pavia province (Italy), in an area belonging to the Po river basin. The area, characterised by different crops and a prevalence of rice cultivation, has a temperate subcontinental climate (Pinna, 1978), and an altitudinal range of $100 \mathrm{~m}$ a.s.l. Rice fields in this area can be classified into two different groups on the basis of rice seeding: water seeded and dry seeded with delayed flooding after 40 days. These paddies are connected by a dense network of irrigation channels and ditches.

The habitats considered were the rice fields handled with different management strategies (Stations 1-5), the adjacent channels (Stations 1-4), and a spring (Station 6) (Tab. 1). Stations 1 and 2 were sampled from 2009 to 2011; Station 5 was sampled in 2009 for 7 months; Stations 3, 4, and 6 were sampled for 12 months in 20102011; some samples could not be collected because of the absence of water. In each station, 4 separate sample replicates were collected monthly in the presence of water. Different management strategies in rice paddies regarded seedling technique and water management, while fertilisation and weed management were conducted similarly in all rice paddies. No insecticide was used during the whole period of observation.

\section{Sampling method}

Benthic macroinvertebrates were sampled with a pond net $\left(30 \times 30 \mathrm{~cm}=0.09 \mathrm{~m}^{2}, 300-\mu \mathrm{m}\right.$ mesh size $)$ used for 30 seconds in the substrate. For chironomids, extra samples of pupae, pupal exuviae, and pharate adults were collected with drift nets (Brundin's net) to confirm species identification. Samples were collected at random along a transect through the habitat considered.

The samples were transported to DeFENS laboratory (University of Milan), where the whole sediment was rinsed using a $0.5 \mathrm{~mm}$ mesh sieve to separate the specimens. The specimens were then stored in 75\% ethyl alcohol and identified to the lowest taxonomic level (species, genus, family)

Tab. 1. Stations description.

\begin{tabular}{lcccc}
\hline Station & Coordinates & Habitat & Water presence (months) & Details \\
\hline 1 Trovo & $45^{\circ} 14^{\prime} 86 \mathrm{~N} ;$ & R1 & 2 & Dry seeded and flooded after 40 days \\
& $9^{\circ} 01^{\prime} 34 \mathrm{E}$ & $\mathrm{C} 1$ & 12 & Smooth flow \\
2 Bereguardo & $45^{\circ} 16^{\prime} 09 \mathrm{~N} ;$ & $\mathrm{R} 2$ & 4 & Water seeded \\
& $9^{\circ} 02^{\prime} 16 \mathrm{E}$ & $\mathrm{C} 2$ & 12 & Water seeded flow \\
3 Zeme Loja & $45^{\circ} 12^{\prime} 42 \mathrm{~N} ;$ & $\mathrm{R} 3$ & 12 & Smooth flow \\
& $8^{\circ} 38^{\prime} 44 \mathrm{E}$ & $\mathrm{C} 3$ & 11 & Water seeded \\
4 Zeme Zanaglia & $45^{\circ} 11^{\prime} 74 \mathrm{~N} ;$ & $\mathrm{R} 4$ & 12 & Smooth flow \\
5 Vigna del Pero & $8^{\circ} 38^{\prime} 25 \mathrm{E}$ & $\mathrm{C} 4$ & 2 & Dry seeded and flooded after 40 days \\
& $45^{\circ} 14^{\prime} 27 \mathrm{~N} ;$ & $\mathrm{R} 5$ & & Spring forming a channel; rippled flow
\end{tabular}

$N$, north; E, east; R1, rice field 1; C1, channel 1; R2, rice field 2; C2, channel 2; R3, rice field 3; C3, channel 3; $R 4$, rice field 4; C4, channel 4; $R 5$, rice field 5; S6, spring 6. 
using a stereomicroscope (Leica MZ 12.5, Leica Microsystems $\mathrm{GmbH}$, Wetzlar, Germany; and Wild Heerbrugg M5A, Leica Geosystems GmbH, Heerbrugg, Switzerland). The identification of many taxa, chironomids and oligochaetes in particular, required dissection of the specimens, the preparation of slides, and examination with an optical microscope (Leica DM LS B2, Leica Microsystems GmbH) connected to a Leica DFC320 camera to obtain measurements. Slides were prepared in Faure medium or Canada balsam. The following taxonomic keys were used in species identification: Olmi (1978), Tamanini (1979), Castagnolo (1980), Girod et al. (1980), Giusti and Pezzoli (1980), Ferrarese and Rossaro (1981), Pirisinu (1981), Rossaro (1982), Belfiore (1983), Ferrarese (1983), Moretti (1983), Wiederholm (1983, 1986, 1989), Nocentini (1985), Friday (1988), Timm (1999), Heidemann and Seidenbush (2002), Cham (2007, 2009). Scientific nomenclature was then updated according to the Fauna Europea inventory (de Jong, 2011).

\section{Environmental variables}

Nine environmental variables, chosen among those routinely measured in biological studies, were considered. Water temperature, $\mathrm{pH}$ and conductivity were measured with a multi-probe field meter (Geotech WTW 3400i Multi-Parameter Field Meter; Geotech Environmental Equipment Inc., Denver, CO, USA) in each locality at each sampling date to characterise the different environments. Water samples were collected at the same sampling date in acid-cleaned graduated bottles for chemical analysis (dissolved $\mathrm{O}_{2}$, alkalinity, hardness, total phosphorus, nitrate nitrogen) by standard methods (APHA, 2005). The grain-size composition of the substrate was evaluated by visual assessment as percentage of stones/rocks $(>20 \mathrm{~cm})$, cobbles $(5 \pm 20 \mathrm{~cm})$, gravel $(0.2 \pm 5 \mathrm{~cm})$, sand $(0.01 \pm 0.2$ $\mathrm{cm})$, and silt $/ \mathrm{mud}(<0.01 \mathrm{~cm})$.

\section{Data analysis}

\section{Diversity}

Diversity is a simple measure which synthesises the community and was selected to have a preliminary measure of the ecological status. The number of species and Shannon diversity index were calculated for all sites (Legendre and Legendre, 2012). Grouped values of diversity according to spatial and temporal factors were also calculated. A factorial ANOVA using the Shannon diversity index as dependent variable and stations, habitats, and months as factors was carried out to estimate the principal sources of variation of diversity.

\section{Indicator values}

The indicator values (IndVal) - a method combining the species mean abundance and its frequency of occur- rence in the groups (Borcard et al., 2011; Legendre and Legendre, 2012) - were calculated to select indicators species in each station and habitat.

The IndVal is the product of two terms: the first (specificity), referring to the performance of species as abundance over all groups, and the other (fidelity), referring to the performance of the same species as presence-absence within site group. These two terms are multiplied and then scaled to express the indicator value of one species with respect to cluster in terms of percentages. Finally, for each species, the higher value is chosen in order to express its indicator value with respect to the habitat examined (Podani and Csányi, 2010).

\section{Self-organising map}

An unsupervised artificial neural network, also known as a self-organising map (SOM) (Kohonen et al., 1995; Vesanto et al., 1999) which is able to visualise and explore linear and non-linear relationships in high-dimensional data sets, was applied (Lek and Guegan, 2000). The purpose was to i) classify all stations, habitats and temporal distribution according to macroinvertebrate assemblages; ii) evaluate differences among rice fields on the basis of the management strategy adopted; and iii) interpret the variability of the observed community in relation to the environmental variables measured.

The structure of the SOM consists of two layers of neurons connected by weights: the input layer consists of a data matrix with $\mathrm{n}$ sampling sites (rows) and $\mathrm{p}$ taxa (columns); the output layer is a matrix with the same column number (p), but a reduced number of rows (rc). The values of the output (codebook matrix) were calculated starting from a principal component solution of the input matrix as initial configuration. The number of rc elements was selected before the calculations began, minimising a quantisation error that measures the distortion of the final configuration compared to the initial one, to select the optimal rc map dimension. This number is a compromise between a too-detailed and too-approximate representation. The SOM aims to minimise the distances between the points in the original input matrix and the ones in the output matrix. To provide a visual geometrical representation, the output neurons were visualised as hexagonal cells in a two-dimensional space, with $r$ rows and columns (where $\mathrm{rc}=\mathrm{r} \times \mathrm{c}$ ). Sites with a similar species composition were clustered in the same output cell. In the training process, each output column vector (neuron) of the codebook matrix was moved from the initial configuration to a new position so that the sum of the distances between the input and output neurons was minimised. The iteration process began moving the codebook neuron having the lowest distance to an input neuron toward the input neuron itself, and continued moving all the other codebook neurons with the aim of minimising the global distance. 
In this sense, the method was similar to nonmetric multidimensional scaling and to other multivariate ordination methods (Legendre and Legendre, 2012). The distribution according to macroinvertebrate assemblages and frequencies of the stations, the habitats and rice fields were plotted in different SOM maps. Each hexagon represented one of the map units $[\mathrm{rc}(\mathrm{r} \times \mathrm{c})=48(6 \times 8)]$. Each element of the output neuron was a cluster of sites, and the values of the output (codebook) matrix quantify the frequencies of each species in the same cluster.

To measure the distance between units of SOM, the Unified distance matrix (U-matrix) was then used. This is a representation of the distances between the sites depicted in a grey scale on a 2-D image. The distance between the adjacent neurons was calculated and presented with different colours between the adjacent nodes: white areas represented compact clusters, while darker areas the gap between different clusters.

The measured environmental variables were subsequently introduced into the SOM map in the attempt to provide a visual representation of the value of each environmental variable in each clustered site.

The species with the highest codebooks and the ones of particular interest (rare, vulnerable, endangered, invasive) were then selected and plotted separately in different maps which could be superimposed to the station and the habitat distribution maps.

\section{Co-inertia}

Co-inertia analysis is a symmetrical approach which associates an environmental variable with a faunistic data set (the taxa) and extracts a simpler data structure from both sets, which are well correlated (Borcard et al., 2011; Legendre and Legendre, 2012). All the taxa detected were included in the co-inertia analysis to relate them with the 9 environmental variables. The between-class analysis (BCA) (Dolédec and Chessel, 1994) was then applied to investigate differences among habitats in the different stations. The BCA is a co-inertia analysis with instrumental variables. In the present case, the instrumental variable was a factor with 10 levels: the habitats in the different stations. First, a correspondence analysis was carried out on the fitted variables of interest [the $\log (\mathrm{x}+1)$-transformed species matrix] after the regression on the instrumental variable; then, a principal component analysis (PCA) was carried out on the fitted environmental variables after the regression on the same instrumental variable. The results of the two analysis were entered in a new co-inertia analysis (Dray et al., 2007). The BCA also allowed to have a joint plot of the instrumental variable: the habitats in the different stations could be represented by an arrow joining the score derived from the environmental set with the score derived by the biological set; a short arrow meant a good agreement between the two sets. The BCA was preferred to other constrained ordination methods (as redundancy analysis), because it allows to plot the instrumental variable in the plane of the principal axes directly.

The R Project for Statistical Computing ${ }^{\circledR}$ (Version 2.15.1) was used to calculate Diversity, IndVal and coinertia. A toolbook of Matlab ${ }^{\circledR}$ (Version R2012A) modified (Lencioni et al., 2007) was used to perform the SOM calculation.

\section{RESULTS}

The 173 taxa captured belong to 4 phyla (Mollusca, Annelida, Nematomorpha, and Arthropoda), 8 classes (Bivalvia, Gastropoda, Oligochaeta, Hirudinea, Gordioida, Insecta, Branchiopoda, and Malacostraca), 24 orders, 68 families, and 127 genera (Tabs. 2, 3, 4, and 5).

Species belonging to different ecological niches were identified. Among Oligochaeta, the abundance of Tubificidae Limnodrilus hoffmeisteri Claparède, 1862 is noteworthy as this species is generally tolerant to low levels of oxygen and organic pollution (Martins et al., 2008). Five families and 6 species of Gastropoda were detected. Among them, the species Bithynia tentaculata (Linnaeus, 1758), Gyraulus albus (Müller, 1774) and Planorbis planorbis (Linnaeus, 1758), considered good indicators of water quality (Dussart, 1979), were very common and widespread. Valvata piscinalis (Müller, 1774) is a relatively tolerant organism, and generally lives in slow or steady waters, mildly polluted (Kalyoncu et al., 2008). Among insects, Odonata, Hemiptera, Coleoptera, and Diptera were well represented: Odonata with 15 species belonging to 7 families, Hemiptera with 10 species from 6 different families, and Coleoptera with 30 species from 8 families. Among Diptera, 15 families were detected. The richest was the family of Chironomidae, with 62 species, including 8 Tanypodinae, 25 Orthocladiinae, 8 Tanytarsini, and 17 Chironomini. Except for the predators Tanypodinae, Cardiocladius fuscus Kieffer, 1924 and Cryptochironomus defectus (Kieffer, 1913), all the other species were grazers (mostly Orthocladiinae), or detritus or filterer feeders (mostly Chironominae). Among Insecta, endangered, vulnerable and rare species were also detected: the Odonata Gomphus flavipes (Charpentier, 1825) and Ophiogomphus cecilia (Fourcroy, 1785) are endangered species (European Commission, 2006; IUCN, 2012); the Coleoptera Hydrophilidae Berosus frotifoveatus Kuwert, 1888, Hydrophilus piceus (Linnaeus, 1758) and Hydrochara caraboides (Linnaeus, 1758) are vulnerable species (Ruffo and Stoch, 2005); the Hemiptera Gerris lateralis Schummel, 1832, the Coleoptera Hydaticus grammicus (Germar, 1830) are rare species (Ruffo and Stoch, 2005). The Diptera Odontomesa fulva (Kieffer, 1919), Diamesa tonsa (Haliday, 1856), and Sympotthastia spinifera Serra-Tosio, 1969 are rare species in lowlands (Ferrarese and Rossaro, 1981). All these species have been detected in channels, while only two Hydrophilidae - the 
predator $H$. piceus and the vegetarian B. frontifoveatus were detected in both rice fields and channels. Berosus frontifoveatus was detected in all stations at different sampling dates, while $H$. piceus was occasionally found only in few.

Few species of Trichoptera (5) and Ephemeroptera (4) were collected. Among Trichoptera, specimens in the family of Hydropsychidae and Limnephilidae are considered good indicators of water quality in natural ponds and rivers (Higler and Tolkamp, 1983; Briers and Biggs, 2003), but here, only the first was abundantly represented by the species Hydropsyche pellucidula (Curtis, 1834), which were found in channels and rarely in rice fields. Among Ephemeroptera, the family of Baetidae and Caenidae are also considered bioindicators in wetlands (Menetrey et al., 2008), but they were poorly detected in the investigated sites.
Some invasive species were identified as well: the Coleoptera Lissorhoptrus oryzophilus Kuschel, 1952 was detected in all sites in both rice fields and channels, the Decapoda Procambarus clarkii (Girard, 1852) and the Bivalvia Corbicula fluminalis (Müller, 1774), was collected only in channels.

In rice paddies, 89 of the 173 taxa sampled have been found. Precisely: 1 Bivalvia, 5 Gastropoda, 6 Oligochaeta, 2 Hirudinea, 74 Insecta (2 Ephemeroptera, 5 Hemiptera, 3 Odonata, 19 Coleoptera, 43 Diptera, 2 Trichoptera) and 1 Malacostraca.

\section{Diversity}

The diversity indices were significantly different with respect to all the factors considered (stations, habitats, and months), with the exception of the number of species between habitats (Tab. 6). The ANOVA results in Tab. 6 show

Tab. 2. List of the taxa found (excluding Insecta).

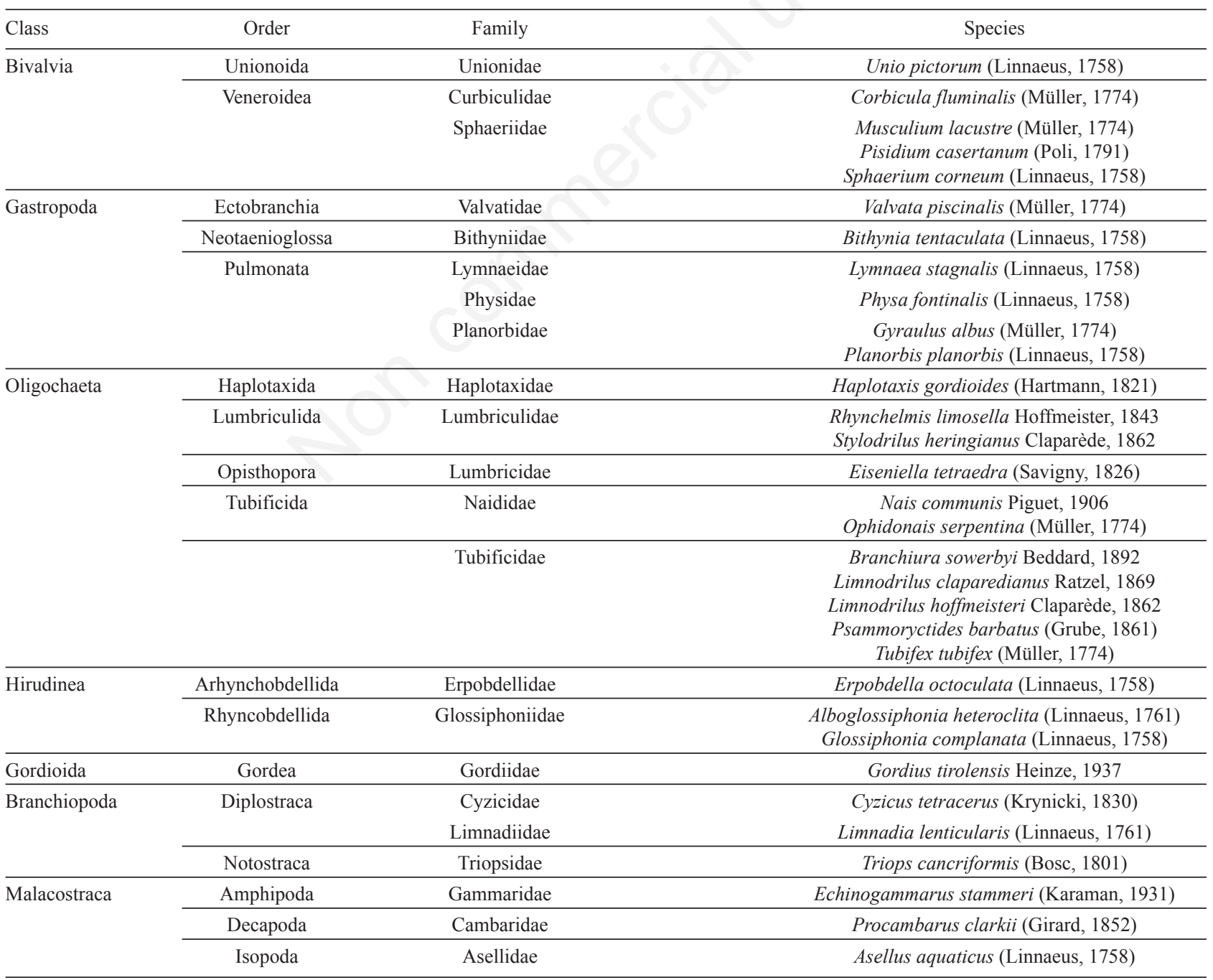


that the habitat is the poorest predictor of the diversity indices. The most significant differences were among months, with the highest diversity indices found in March, April and September (Tab. 6 and Fig. 1a). The number of species and the Shannon diversity index were highest in Station 4, where the feeding channel (C4) contributed more to diversity than the rice field itself (R4) (Figs. 1b and 1c). The same analysis applied to rice fields subject to different management strategies highlighted that the lowest diversity was observed in Station 5, one of the two stations with the shorter period of flooding. Diversity was always higher in feeding channels than in rice fields (Figs. 1c and 1d).

\section{Indicator values}

Using the 10 habitats in the different stations as factor, the IndVal analysis allowed to detect 18 taxa (Tab. 7). At least one indicator species was detected in each station. The analysis pointed out that all the channels have at least one species with $\mathrm{P}<0.05$. As far as rice paddies are concerned, R1 was characterised by Triops cancriformis (Bosc, 1801), Enochrus quadripunctatus (Herbst, 1797), Chironomus plumosus (Linnaeus, 1758), Alboglossiphonia heteroclita (Linnaeus, 1761), Serratella ignita (Poda, 1761), R3 by Sigara lateralis (Leach, 1817), Orthetrum albistylum (Sélys, 1848), G. albus, Helochares lividus (Forster, 1771), Stratiomyidae and Ephydridae, and R5 by Cryptochironomus defectus (Kieffer, 1913) (Tab. 7). No indicator species were found in R2 and R4. Only the species Microtendipes pedellus (De Geer, 1776) was indicator of the spring (S6).

Tab. 3. List of the species of insects detected (excluding Diptera and Coleoptera).

\begin{tabular}{|c|c|c|c|}
\hline Class & Order & Family & Species \\
\hline \multirow[t]{23}{*}{ Insecta } & \multirow[t]{4}{*}{ Ephemeroptera } & Baetidae & Baetis rhodani (Pictet, 1843) \\
\hline & & Caenidae & Caenis horaria (Linnaeus, 1758) \\
\hline & & Ephemerellidae & Serratella ignita (Poda, 1761) \\
\hline & & Oligoneuriidae & Oligoneuriella rhenana (Imhoff, 1852) \\
\hline & \multirow[t]{7}{*}{ Odonata } & Aeshnidae & Aeshna cyanea (Müller, 1764) \\
\hline & & Calopterygidae & Calopteryx splendens (Harris, 1782) \\
\hline & & Coenagrioniidae & $\begin{array}{c}\text { Coenagrion puella (Linnaeus, 1758) } \\
\text { Ischnura elegans (Vander Linden, 1820) }\end{array}$ \\
\hline & & Gomphidae & $\begin{array}{c}\text { Gomphus flavipes (Charpentier, 1825) } \\
\text { Gomphus vulgatissimus (Linnaeus, 1758) } \\
\text { Onychogomphus uncatus (Charpentier, 1840) } \\
\text { Ophiogomphus cecilia (Fourcroy, 1785) }\end{array}$ \\
\hline & & Lestidae & Lestes sponsa (Hansemann, 1823) \\
\hline & & Libellulidae & $\begin{array}{l}\text { Libellula quadrimaculata Linnaeus, } 1758 \\
\text { Orthetrum albistylum (Sélys, 1848) } \\
\text { Orthetrum cancellatum (Linnaeus, 1758) } \\
\text { Orthetrum coerulescens (Fabricius, 1798) } \\
\text { Sympetrum pedemontanum (Allioni, 1766) }\end{array}$ \\
\hline & & Platycnemididae & Platycnemis pennipes (Pallas, 1771) \\
\hline & \multirow[t]{6}{*}{ Hemiptera } & Corixidae & $\begin{array}{l}\text { Sigara dorsalis (Leach, 1817) } \\
\text { Sigara italica Jaczewski, 1933 } \\
\text { Sigara lateralis (Leach 1817) }\end{array}$ \\
\hline & & Gerridae & $\begin{array}{c}\text { Aquarius najas (De Geer, 1773) } \\
\text { Aquarius paludum (Fabricius, 1794) } \\
\text { Gerris lateralis Schummel, } 1832\end{array}$ \\
\hline & & Hydrometridae & Hydrometra stagnorum (Linnaeus, 1758) \\
\hline & & Naucoridae & Ilyocoris cimicoides (Linnaeus, 1758) \\
\hline & & Nepidae & Nepa cinerea Linnaeus, 1758 \\
\hline & & Notonectidae & Notonecta maculata Fabricius, 1794 \\
\hline & \multirow[t]{5}{*}{ Trichoptera } & Hydropsychidae & Hydropsyche pellucidula (Curtis, 1834) \\
\hline & & Hydroptilidae & Hydroptila aegyptia Ulmer, 1963 \\
\hline & & Lepidostomatidae & Lepidostoma hirtum (Fabricius, 1775) \\
\hline & & Leptoceridae & Ceraclea dissimilis (Stephens, 1836) \\
\hline & & Limnephilidae & Limnephilus flavicornis (Fabricius, 1787) \\
\hline & Lepidoptera & Crambidae & Cataclysta lemnata (Linnaeus, 1758) \\
\hline
\end{tabular}




\section{Self-organising map}

The SOM analysis allowed to detect major differences among stations (Fig. 2a) and habitats (Fig. 2b). The analysis of the different rice management strategies allocated only the rice field characterised by 11 months of submersion (R4) in a separated cluster (Fig. 2c). The U-matrix (Fig. 3a) shows that well separated clusters of stations cannot be defined according to species distribution.

In Fig. 4, the 12 species with the highest codebook are presented with their distribution in the SOM map. Most species were mapped in the bottom left part of the map evidencing a preference for channels (Fig. 2b) characterised by a larger granulometry (Fig. 3b). Among them, Cricotopus sylvestris (Fabricius, 1794), Calopteryx splendens (Harris, 1782), H. pellucidula, Lymnaea stagnalis (Linnaeus, 1758), Eiseniella tetraedra (Savigny, 1826), L. hoffmeisteri, B. tentaculata, Chironomus riparius Meigen, 1804 were found (Fig. 4). Interestingly, C. riparius, B. tentaculata, L. hoffmeisteri and E. tetraedra were detected in stations with high total phosphorus (TP) concentration (Fig. 3c).

Hydroglyphus geminus (Fabricius, 1792) and Sigara dorsalis (Leach, 1817), were most represented in a cluster of sites in the bottom right side of the SOM map; this cluster included both rice ponds and channels with lower granulometry and temperature (Figs. $3 \mathrm{~b}$ and $3 \mathrm{c}$ ).

Gyraulus albus and Physa fontinalis were mapped in the bottom part of the SOM map where both rice paddies and channels were clustered, regardless of the environmental variables and the agronomic management.

In Fig. 5, endangered, vulnerable, rare and invasive species are given. The endangered species G. flavipes and $O$. cecilia were respectively mapped in the bottom left and in the central right. Both areas were representative of channels but were characterised by a different granulometry. Among vulnerable species, $H$. caraboides was mapped in the higher part of the SOM map showing a clear preference for the spring. The rare G. lateralis and H. grammicus were clustered in the bottom left part of the SOM map with a clear preference for channels (Figs. 2, 3 and 5). The invasive species L. oryzophilus was mapped in different areas corresponding to channels and rice fields regardless of the management strategies adopted and the environmental variables. C. fluminalis was mapped in the

Tab. 4. List of the species of Coleoptera detected.

\begin{tabular}{|c|c|c|c|}
\hline Class & Order & Family & Species \\
\hline \multirow[t]{8}{*}{ Insecta } & Coleoptera & Brachyceridae & Lissorhoptrus oryzophilus Kuschel, 1952 \\
\hline & & Dryopidae & Dryops luridus (Erichson, 1847) \\
\hline & & Dytiscidae & $\begin{array}{c}\text { Hydaticus grammicus (Germar, 1830) } \\
\text { Hydroglyphus geminus (Fabricius, 1792) } \\
\text { Hydroporus marginatus (Duftschmid, 1805) } \\
\text { Hydrovatus cuspidatus Kunze, 1818 } \\
\text { Hygrotus impressopunctatus (Schaller, 1783) } \\
\text { Hygrotus inaequalis (Fabricius, 1776) } \\
\text { Laccophilus hyalinus De Geer, 1774 } \\
\text { Laccophilus minutus (Linnaeus, 1758) } \\
\text { Laccophilus poecilus Klug, 1834 } \\
\text { Rhantus suturalis (MacLeay, 1825) }\end{array}$ \\
\hline & & Elmidae & $\begin{array}{c}\text { Elmis maugetii Latreille, } 1798 \\
\text { Limnius volckmari (Panzer, 1793) }\end{array}$ \\
\hline & & Gyrinidae & Aulonogyrus concinnus (Klug, 1834) \\
\hline & & Haliplidae & $\begin{array}{c}\text { Haliplus fulvus (Fabricius, 1801) } \\
\text { Haliplus laminatus (Schaller, 1783) } \\
\text { Haliplus lineaticollis (Marsham, 1802) } \\
\text { Haliplus flavicollis Sturm, } 1834 \\
\text { Haliplus heydeni Wehncke, 1875 } \\
\text { Peltodytes caesus (Duftschmid, 1805) }\end{array}$ \\
\hline & & Helophoridae & Helophorus brevipalpis Bedel, 1881 \\
\hline & & Hydrophilidae & $\begin{array}{c}\text { Berosus signaticollis Charpentier, } 1825 \\
\text { Berosus frontifoveatus Kuwert, } 1888 \\
\text { Enochrus melanocephalus (Olivier, 1792) } \\
\text { Enochrus quadripunctatus (Herbst, 1797) } \\
\text { Helochares lividus (Forster, 1771) } \\
\text { Hydrochara caraboides (Linnaeus, 1758) } \\
\text { Hydrophilus piceus (Linnaeus, 1758) } \\
\text { Laccobius minutus (Linnaeus, 1758) }\end{array}$ \\
\hline
\end{tabular}


Tab. 5. List of the Diptera detected.

\begin{tabular}{lcccc}
\hline Class & Order & Family & Species \\
& & Subfamily & Tribe
\end{tabular}

Insecta

Diptera

Ceratopogonidae

Chironomidae

\begin{tabular}{|c|c|}
\hline Tanypini & Tanypus punctipennis Meigen, 1818 \\
\hline Procladini & Procladius choreus (Meigen, 1804) \\
\hline Pentaneurini & $\begin{array}{c}\text { Ablabesmyia longistyla Fittkau, 1962 } \\
\text { Ablabesmyia monilis (Linnaeus, 1758) } \\
\text { Arctopelopia griseipennis (van der Wulp, 1858) } \\
\text { Conchapelopia pallidula (Meigen, 1818) } \\
\text { Thienemannimyia carnea (Fabricius, 1805) } \\
\text { Zavrelimyia punctatissima (Goetghebuer, 1934) }\end{array}$ \\
\hline Diamesinae & $\begin{array}{l}\quad \text { Diamesa tonsa (Haliday, 1856) } \\
\text { Sympotthastia spinifera Serra-Tosio, } 1969\end{array}$ \\
\hline Prodiamesinae & $\begin{array}{c}\text { Prodiamesa olivacea (Meigen, 1818) } \\
\text { Odontomesa fulva (Kieffer, 1919) }\end{array}$ \\
\hline Orthocladiinae & $\begin{array}{c}\text { Brillia bifida (Kieffer, 1909) } \\
\text { Brillia longifurca Kieffer, 1921 } \\
\text { Cardiocladius fuscus Kieffer, 1924 } \\
\text { Corynoneura scutellata Winnertz, 1846 } \\
\text { Cricotopus annulator Goetghebuer, 1927 } \\
\text { Cricotopus bicinctus (Meigen, 1818) } \\
\text { Cricotopus fuscus (Kieffer, 1909) } \\
\text { Cricotopus trifascia Edwards, 1929 } \\
\text { Cricotopus sylvestris (Fabricius, 1794) } \\
\text { Eukiefferiella claripennis (Lundbeck, 1898) } \\
\text { Limnophyes minimus (Meigen, 1818) } \\
\text { Orthocladius luteipes Goetghebuer, 1938 } \\
\text { Orthocladius rivicola Kieffer, 1911 } \\
\text { Orthocladius thienemanni Kieffer, 1906 } \\
\text { Orthocladius excavatus Brundin, 1947 } \\
\text { Orthocladius oblidens (Walker, 1856) } \\
\text { Orthocladius rhyacobius Kieffer, 1911 } \\
\text { Orthocladius rubicundus (Meigen, 1818) } \\
\text { Paracladius conversus (Walker, 1856) } \\
\text { Parametriocnemus stylatus (Spaerck, 1923) } \\
\text { Paratrichocladius rufiventris (Meigen, 1830) } \\
\text { Psectrocladius sp. Kieffer, 1906 } \\
\text { Rheocricotopus chalybeatus (Edwards, 1929) } \\
\text { Rheocricotopus fuscipes (Kieffer, 1909) } \\
\text { Smittia pratorum (Goetghebuer, 1927) }\end{array}$ \\
\hline
\end{tabular}

Chironominae

Tanytarsini

Cladotanytarsus atridorsum Kieffer, 1924

Micropsectra atrofasciata (Kieffer, 1911)

Paratanytarsus lauterborni (Kieffer, 1909)

Tanytarsus brundini Lindeberg, 1963

Tanytarsus ejuncidus (Walker, 1856)

Tanytarsus eminulus (Walker, 1856)

Tanytarsus volgensis Miseiko, 1967

Virgatanytarsus triangularis (Goetghebuer, 1928)

Chironomini

Chironomus dorsalis Meigen, 1818

Chironomus plumosus (Linnaeus, 1758)

Chironomus riparius Meigen, 1804

Cryptochironomus defectus (Kieffer, 1913)

Dicrotendipes nervosus (Staeger, 1839)

Endochironomus tendens (Fabricius, 1775)

Harnischia fuscimanus Kieffer, 1921

Microtendipes pedellus (De Geer, 1776)

Paratendipes albimanus (Meigen, 1818)

Pentapedilum tritum (Walker, 1856)

Phaenopsectra flavipes (Meigen, 1818)

To be continued on next page. 
Tab. 5. Continued from previous page.

\begin{tabular}{|c|c|c|c|}
\hline \multicolumn{4}{|c|}{$\begin{array}{ll}\text { Subfamily } & \\
& \text { Tribe }\end{array}$} \\
\hline & & Chironomini & $\begin{array}{l}\text { Polypedilum convictum (Walker, 1856) } \\
\text { Polypedilum laetum (Meigen, 1818) } \\
\text { Polypedilum nubeculosum (Meigen, 1804) } \\
\text { Polypedilum scalaenum (Schrank, 1803) } \\
\text { Stenochironomus ranzii Rossaro, 1982 } \\
\text { Synendotendipes impar (Walker, 1856) }\end{array}$ \\
\hline Insecta & Diptera & $\begin{array}{l}\text { Culicidae } \\
\text { Dolichopodidae } \\
\text { Ephydridae } \\
\text { Limoniidae } \\
\text { Muscidae } \\
\text { Psychodidae } \\
\text { Rhagionidae } \\
\text { Sciomyzidae } \\
\text { Simuliidae } \\
\text { Stratiomyidae } \\
\text { Syrphidae } \\
\text { Tabanidae } \\
\text { Tipulidae }\end{array}$ & \\
\hline
\end{tabular}

Tab. 6. Analysis of variance carried out on Shannon diversity index and the number of species found.

\begin{tabular}{|c|c|c|c|c|c|c|}
\hline Shannon & Df & Sum Sq & Mean Sq & $F$ value & $\operatorname{Pr}(>F)$ & \\
\hline Stations & 5 & 5.607 & 1.121 & 3.214 & 0.0106 & $*$ \\
\hline Habitats & 2 & 2.076 & 2.076 & 5.949 & 0.0169 & $*$ \\
\hline Months & 11 & 9.683 & 0.880 & 2.523 & 0.0086 & $* *$ \\
\hline Number of species & Df & Sum Sq & Mean Sq & F value & $\operatorname{Pr}(>\mathrm{F})$ & \\
\hline Stations & 5 & 1183 & 236.56 & 4.104 & 0.0022 & $* *$ \\
\hline Habitats & 2 & 158 & 158.17 & 2.744 & 0.1014 & \\
\hline Months & 11 & 2566 & 233.27 & 4.047 & 0.0001 & $* * *$ \\
\hline
\end{tabular}

Df, degree of freedom; Sum Sq, sum of squares; Mean Sq, mean square.

Tab. 7. Indicator species with the higher indicator value using habitats as factor.

\begin{tabular}{lccc}
\hline Species & IndVal & Station/Habitat & P \\
\hline L. hoffmeisteri & 0.449 & $\mathrm{C} 1$ & 0.026 \\
T. cancriformis & 0.490 & $\mathrm{R} 1$ & 0.006 \\
E. quadripunctatus & 0.511 & $\mathrm{R} 1$ & 0.008 \\
C. plumosus & 0.432 & $\mathrm{R} 1$ & 0.013 \\
A. heteroclita & $\mathrm{R} 1$ & 0.014 \\
H. pellucidula & $\mathrm{C} 2$ & 0.015 \\
Simuliidae & 0.433 & $\mathrm{C} 2$ & 0.012 \\
L. stagnalis & 0.421 & $\mathrm{C} 3$ & 0.009 \\
S. lateralis & 0.450 & $\mathrm{R} 3$ & 0.012 \\
Stratiomyidae & $\mathrm{R} 3$ & 0.021 \\
O. albistylum & $\mathrm{R} 3$ & 0.027 \\
Ephydridae & 0.390 & $\mathrm{R} 3$ & 0.035 \\
G. albus & 0.421 & $\mathrm{R} 3$ & 0.036 \\
H. lividus & 0.438 & $\mathrm{R} 3$ & 0.022 \\
E. stammeri & $\mathrm{C} 4$ & 0.027 \\
V. piscinalis & $\mathrm{C} 4$ & 0.042 \\
C. defectus & 0.355 & $\mathrm{R} 5$ & 0.013 \\
M. pedellus & 0.274 & $\mathrm{~S} 6$ &
\end{tabular}

IndVal, indicator values; C1, channel 1; R1, rice field 1; C2, channel 2; C3, channel 3; R3, rice field 3; C4, channel 4; R5, rice field 5; S6, spring 6. Only species with $P<0.05$ are listed. 
upper part of the SOM map with channels and spring prevailing and $C$. clarkii mostly in the bottom left part of the SOM map where channels were represented.

\section{Co-inertia}

The results of co-inertia analysis highlighted a good agreement between the two sets of variables, as emphasised by their high correlations (Tab. 8). The scatter plot of the BCA results is provided in Fig. 6. According to the eigenvalues barplot, more than $70 \%$ of the variance of the co-inertia analysis was accounted for by the first two coinertia axes and thus presented a good initial summary of the co-structure between the two datasets. In the plot of $\mathrm{X}$ canonical weights (environmental variables), the first axis separated sites with high dissolved oxygen from those with high conductivity, hardness, and alkalinity; the second axis separated sites with high temperature, granulometry, and TP from those with high nitrate and $\mathrm{pH}$. The result is that differently managed rice fields were characterised by different environmental variables and species: low oxygen content and high TP characterised rice fields (R1) and channels ( $\mathrm{C} 1$ and $\mathrm{C} 3$ ); high granulometry and water temperature typified the channel $\mathrm{C} 2$; high conductivity and alkalinity characterised rice fields R3, R4 and S6; and high oxygen and nitrate content identified R2 and C4. A joint plot of sites scores, calculated starting from both environmental and species variables, emphasises the good agreement between the 2 sets, which is especially evident in $\mathrm{C} 1$ and $\mathrm{C} 4$.

In the plot of $\mathrm{Y}$ canonical weights (species), some species were able to characterise different habitats: in the area with high TP concentration, L. hoffmeisteri characterised channel C1; Peltodytes caesus (Duftschmid, 1805) channel C3; C. plumosus and T. cancriformis rice field
R1. In the area with high conductivity and alkalinity, $B$. frontifoveatus and Ephydridae were characteristic of R3; Hydrometra stagnorum (Linnaeus, 1758), Aulonogyrus concinnus (Klug, 1834), H. caraboides and M. pedellus were typical of the spring. In the area with high oxygen and nitrate content (C4), there were 15 taxa superimposed: among them, Lestes sponsa (Hansemann, 1823), Aquarius najas (De Geer, 1773), Haliplus laminatus (Schaller, 1783), Cataclista lemnata (Linnaeus, 1758), Limnadia lenticularis (Linnaeus, 1761), Rhagionidae, and 9 Chironomidae with the rare species $D$. tonsa and S. spinifera. The remaining species were not separated in specific clusters as they were not correlated with the environmental variables and consequently with the different habitats. As a result, they were allocated in the central part of the plot. Among them, the invasive and the most abundantly detected species were present.

\section{DISCUSSION}

The current study highlighted the high species richness of rice agroecosystems in agreement with Della Bella et al. (2005) on the conservation status of natural temporary ponds in Italy. The number of species found (173) was high if we consider that the ecosystems examined are subject to intense anthropogenic impact, and this emphasises the importance of rice cultivation areas in supporting wetland conservation. Water in paddies and channels favours the development of species competitive to those damaging rice; these competitors belong to different ecological niches: phytophagous, predators, saprophagous, and phytosaprophagous.

In rice paddies the number of species found (89) is similar to the results obtained in other researches in Europe (Portugal) and in Asia (Sri Lanka) (Bambaradeniya

Tab. 8. Co-inertia analysis results: eigenvalue decomposition of the matrix of co-inertia, eigenvalues, covariance, and standard deviation of the two sets of sites scores on the co-inertia axes and correlations between the two sets of site scores. The inertia of the cumulated projections of the $\mathrm{X}$ and $\mathrm{Y}$ tables as projected in the co-inertia analysis (CoIA) compared with the maximum inertia of the axes of the separate ordinations, the ratio of these values measures the concordance between the 2 projections.

\begin{tabular}{|c|c|c|c|c|c|c|c|}
\hline & & Eig & Covar & $\operatorname{sdX}$ & sdY & Corr & \\
\hline & 1 & 0.393 & 0.627 & 0.489 & 1.619 & 0.792 & \\
\hline & 2 & 0.345 & 0.588 & 0.581 & 1.230 & 0.823 & \\
\hline & 3 & 0.209 & 0.457 & 0.553 & 1.063 & 0.778 & \\
\hline & 4 & 0.136 & 0.369 & 0.490 & 1.051 & 0.716 & \\
\hline $\mathrm{X}$ & Inertia & Max & Ratio & Y & Inertia & Max & Ratio \\
\hline 1 & 0.239 & 0.581 & 0.412 & 1 & 2.622 & 2.746 & 0.955 \\
\hline 12 & 0.576 & 1.150 & 0.501 & 12 & 4.134 & 4.413 & 0.937 \\
\hline 123 & 0.882 & 1.641 & 0.538 & 123 & 5.264 & 5.610 & 0.938 \\
\hline 1234 & 1.122 & 2.119 & 0.530 & 1234 & 6.369 & 6.481 & 0.983 \\
\hline
\end{tabular}

Eig, eigenvalues; Covar, covariance; $s d X$, standard deviation of the environmental variables of sites scores on the co-inertia axes $X$; sdY, standard deviation of the species of sites scores on the co-inertia axes $Y$; Corr, correlations between the two sets of site scores; $X, X$ axes; $Y, Y$ axes; Max, maximum inertia of the axes of the separate ordinations. 

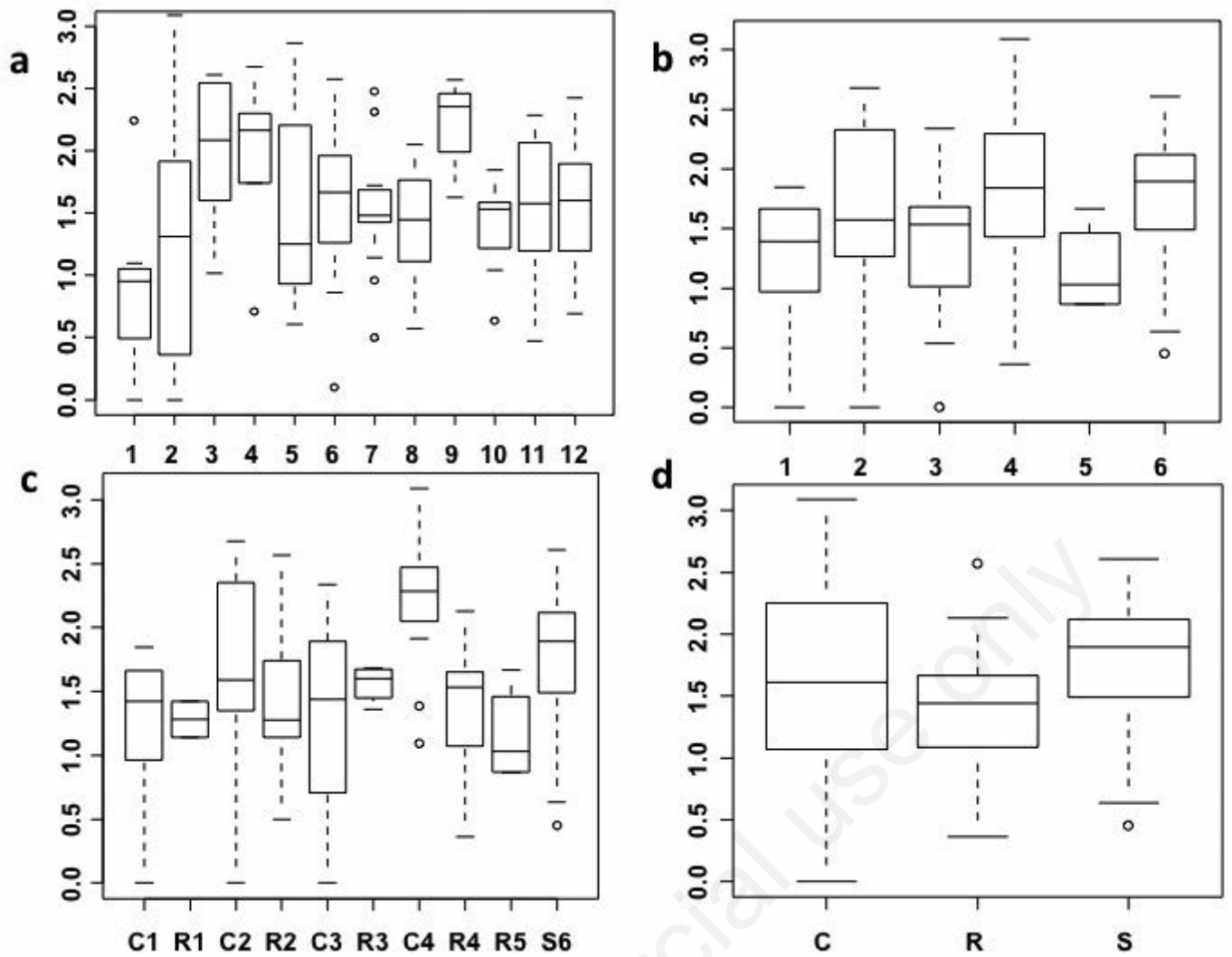

Fig. 1. Box and whisker plots for the Shannon diversity index. Grouping factors are: a) months, b) stations, c) habitats/stations, and d) habitats. [The box lines are median values, while the box ends are quartiles; whiskers show the ranges (non-outliers within an interval of $1.5 \times$ height of the box), and the circles indicate outliers].

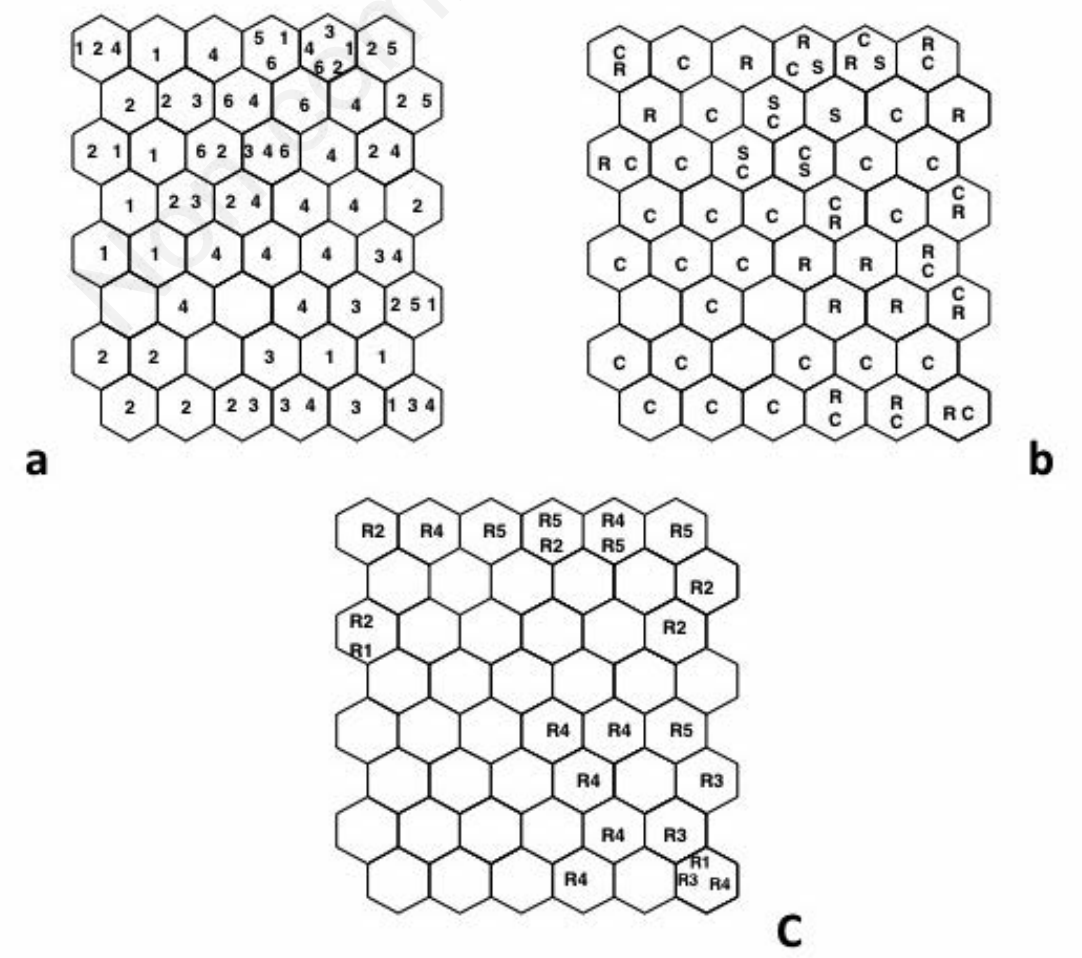

Fig. 2. Self-organising maps (SOMs): a) six stations; b) rice fields and channels; c) rice fields in different habitats. 

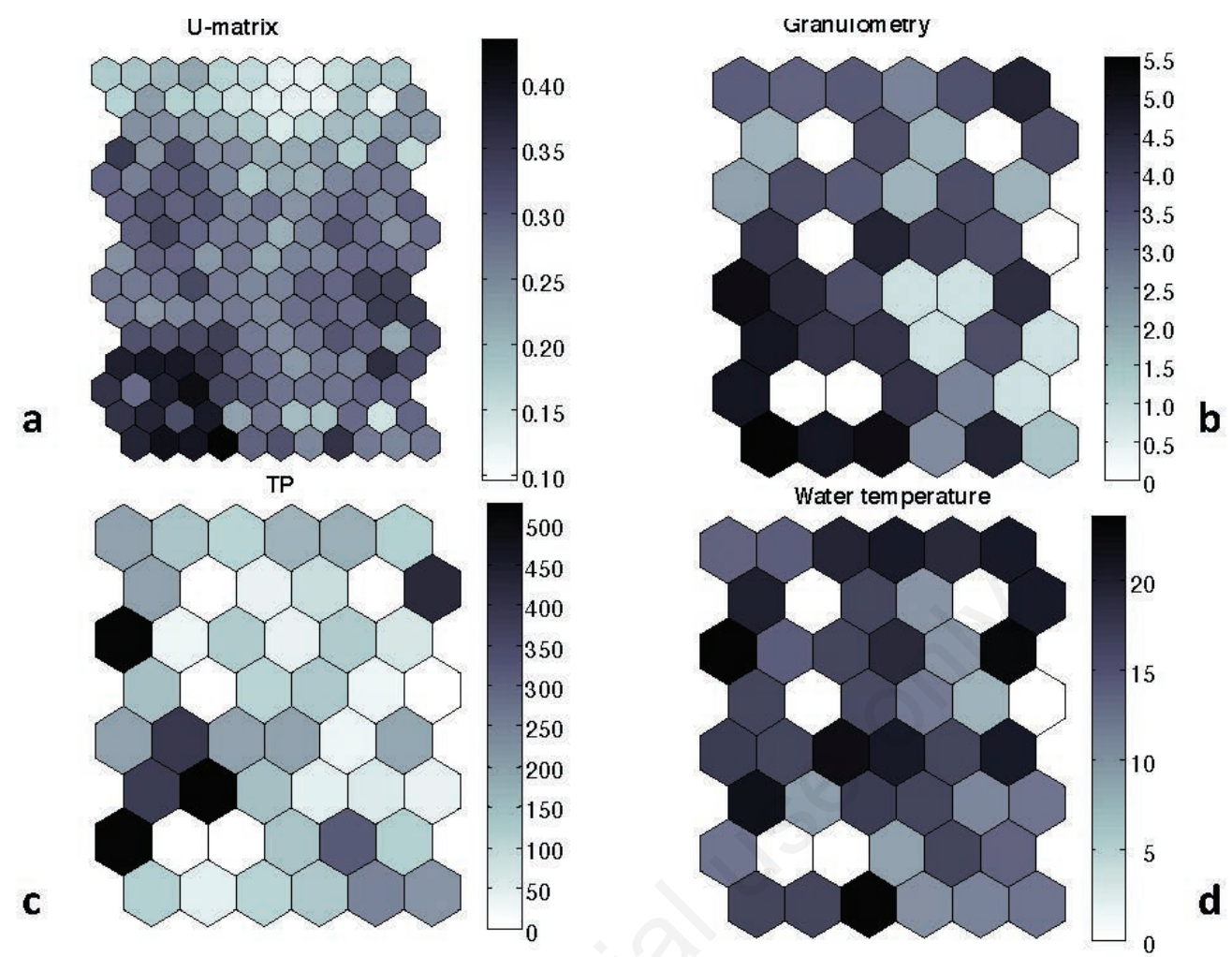

Fig. 3. Self-organising maps (SOMs): a) U-matrix (the scale bar on the right side is the distance between clusters); b) granulometry; c) total phosphorus (TP); d) water temperature with visualisation in shading scale (dark=high value, light=low value). The scale bars on the right side of each map show the value of the environmental variable.
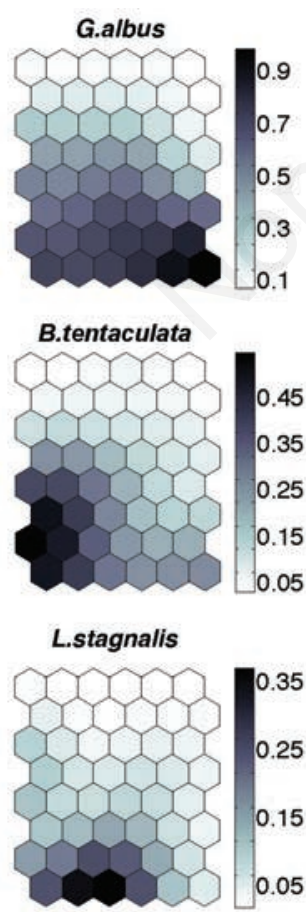

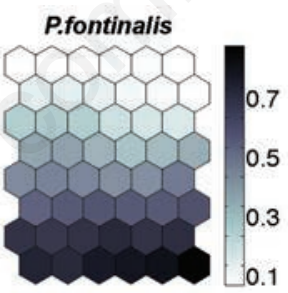

S.dorsalis

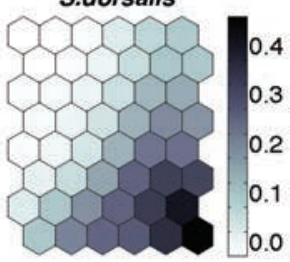

H.pellucidula

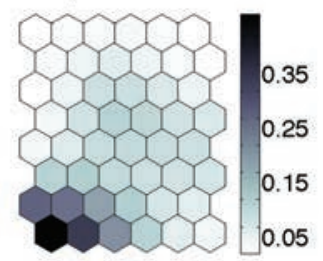

H.geminus

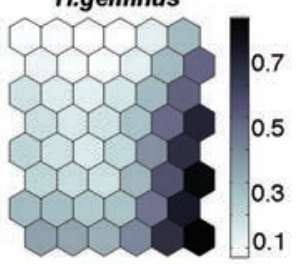

L.hoffmeisteri

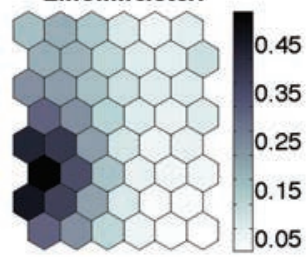

C.splendens

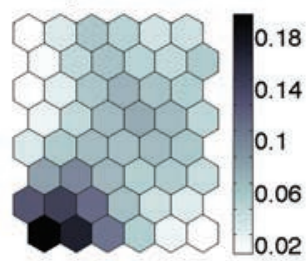

C.riparius

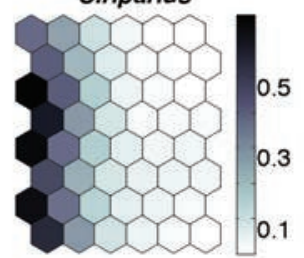

E.tetraedra

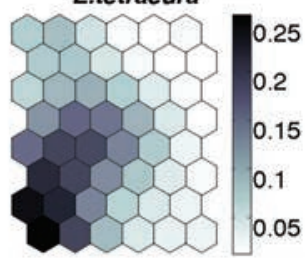

I.sylvestris

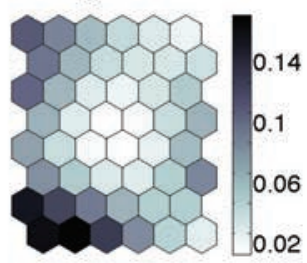

Fig. 4. Self-organising maps (SOMs) of the 12 species with the highest codebook, with visualisation in shading scale (dark=high codebook values, light=low codebook values). The scale bars on the right side of each map show the coded abundance of each taxon. 
et al., 2004; Leitão et al., 2007). More than the half of the species of Gastropoda and Coleoptera and at least half of the species of Oligochaeta, Hirudinea, Ephemeroptera, Hemiptera, Diptera and Trichoptera have been detected. Among them, some Coleoptera (Dytiscidae, Haliplidae, and Hydrophilidae) and many Oligochaeta are known as very resistant taxa (Lafont, 1984; Smith and Golladay, 2011). Despite showing low resistance, different taxa show high resilience recovering rapidly from different disturbances; among them, Baetidae and many Chironomidae (Viera et al., 2004). Species with longer cycle like some dragonflies were localised mostly in channels. Dragonflies such as C. splendens were found in rice fields, but as they develop over two years and overwinter buried in mud it is doubtful whether they can complete their development in this habitat. No Odonata was captured in rice paddies with shorter water period (Stations: $\mathrm{R} 1$ and R5). On the contrary, rice fields resulted to be valuable places for small water beetles able to fly in channels when the condition in paddies were unfavourable (e.g., H. geminus and Laccophilus spp.).

The detection of rare species, with no apparent contribution to community stability or ecosystem functioning, draws attention to the role these environments play in bio- diversity conservation, emphasising the value of less abundant species which may be at higher risk of extinction. Conversely, the presence of exotic invasive species such as the rice water weevil L. oryzophilus and P. clarkii may become a serious threat for biodiversity (Jucker and Lupi, 2011). Most importantly, in the study period no insecticide was registered for the control of the rice water weevil, but further researches are needed to evaluate the impact on biodiversity of either agronomic or chemical treatments applied in the control of this pest.

The interaction of the different methods of data analysis allowed a more comprehensive view on the value of the components of rice agroecosystems. All the data analyses highlighted significant differences between habitats (feeding channel and rice field), with higher diversity observed in channels; this is in agreement with the wellknown differences generally observed between fauna living in lentic and lotic habitats (Maroneze et al., 2011). Biodiversity indices stressed a significant influence of the season, which is in line with the variation of the community composition during the year according to the life cycles of different species (Barbone et al., 2012). According to management practices, lower biodiversity values were found in one of the rice fields characterised by a shorter

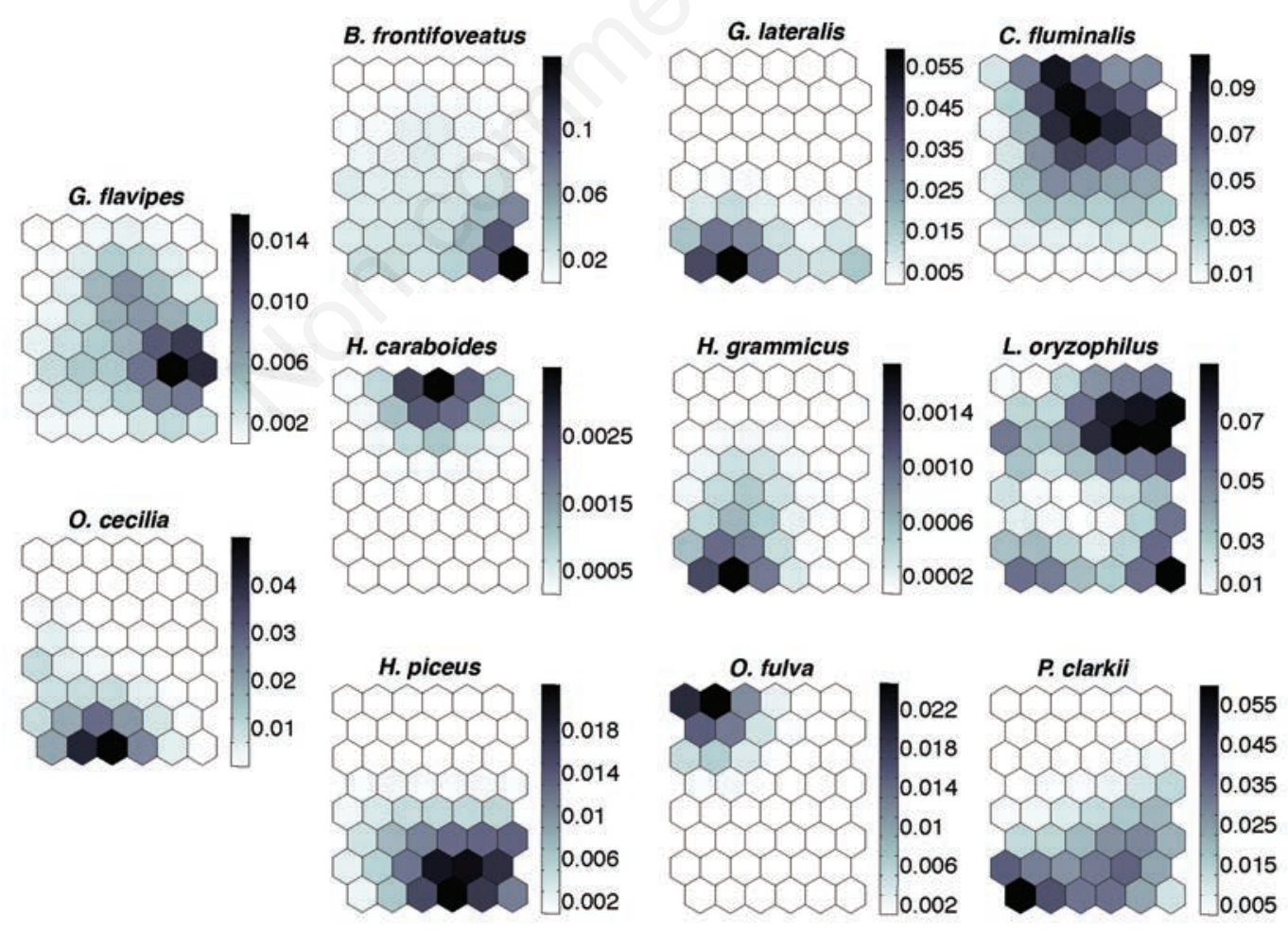

Fig. 5. Self-organising maps (SOMs) of, respectively, from the left to the right: endangered, vulnerable, rare and invasive species with visualisation in shading scale (dark=high codebook values, light=low codebook values). The scale bars on the right side of each map show the coded abundance of each taxon. 
period of flooding (R5), underlining the role of water permanence on species biodiversity. Contrary to our expectations, the spring (S6), which was not subject to any impact bound to rice cultivation, gave biodiversity indices only a bit higher than in other agroecosystems (e.g. Station 4). These results point out that diversity may be useful to measure stress determined by rice-crop management, but it is a rough index not well suited to detect subtle impacts.

The IndVal analysis gave a somewhat more informative result, highlighting variations among stations and habitats. Channels were characterised by many indicator species which brought to light differences in the quality of the water channels. The indicator species L. hoffmeisteri present in $\mathrm{C} 1$ was indicator of bad quality of the water, as highlighted also by BCA; in fact, $H$. pellucidula and Echinogammarus stammeri (Karaman, 1931), found respectively in $\mathrm{C} 2$ and $\mathrm{C} 4$, were indicators of good water quality (Galli et al., 2001). Few species resulted to be able to characterise rice fields. Among them, taxa with very short life cycles as Chironomidae, Ephydridae, and T. cancriformis resulted to be indicators. Two Hydrophilidae characterised different rice fields: E. quadripunctatus, typical of smooth, astatic water, and of an environment

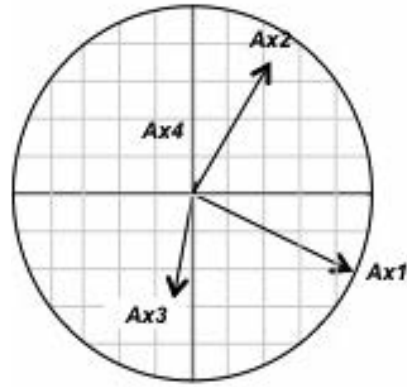

X axes

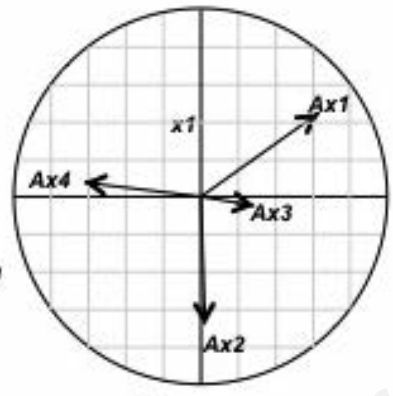

Y axes

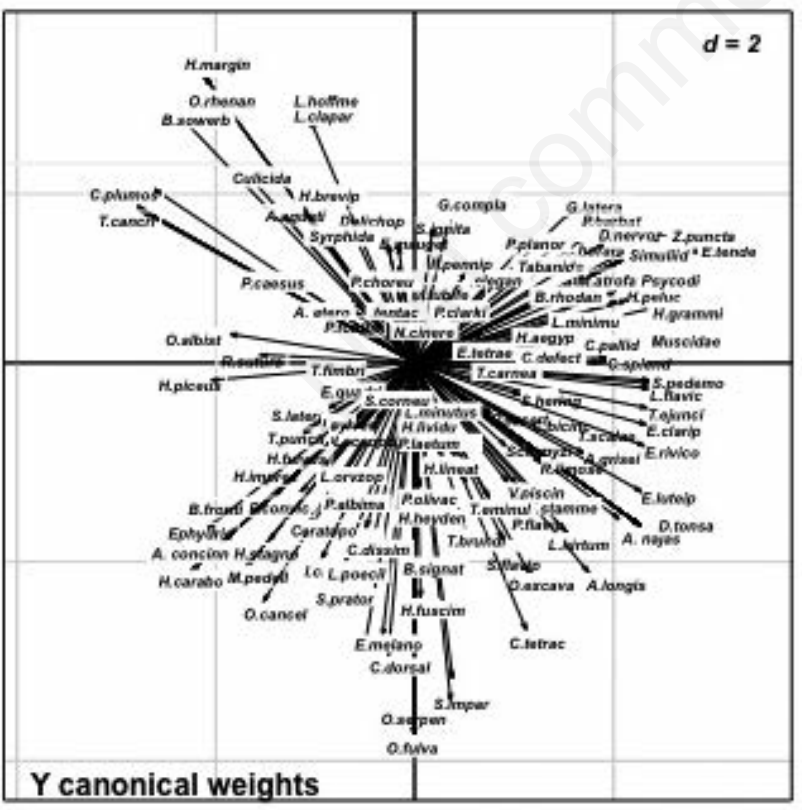

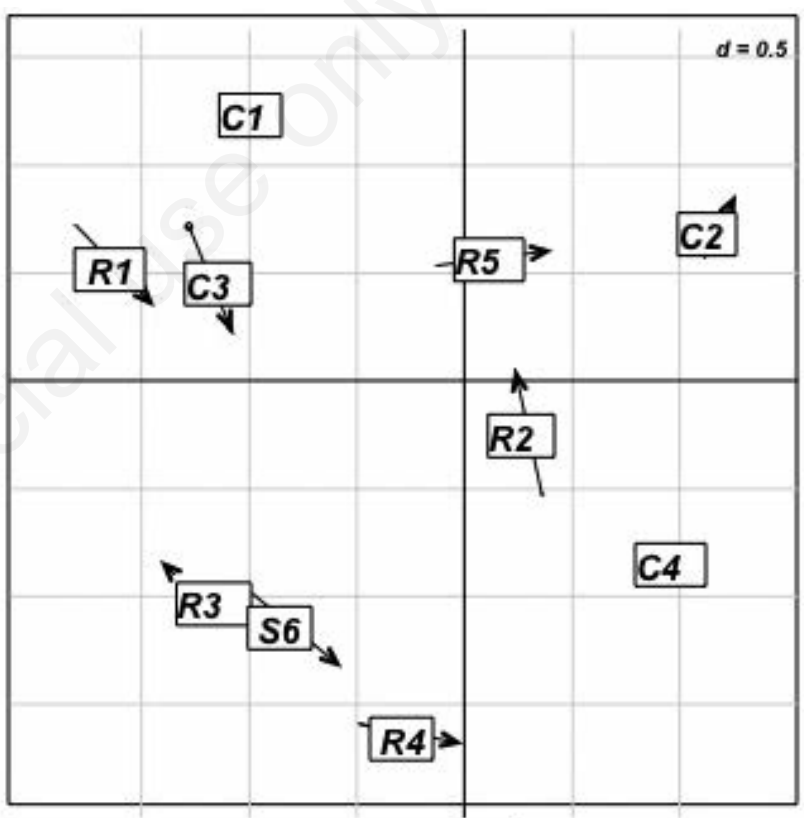
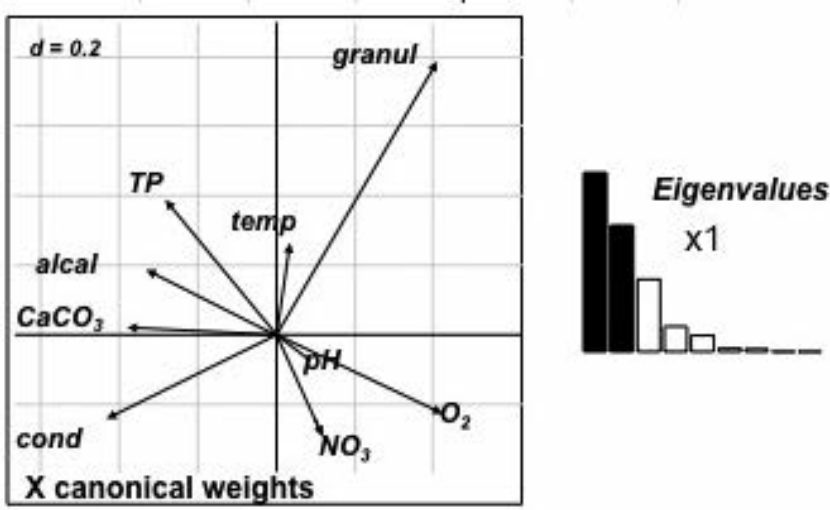

Fig. 6. Between class co-inertia analysis carried out with the habitats in the different stations as instrumental variables. The upper-left circular plots show the position of the principal component analysis (environmental variables) and CoA (species) axes with respect to the Co-inertia analysis (CoIA) axes. The lower-right barplot indicates the eigenvalues. The upper right-hand plot shows the position of the habitats in the different stations on the first two co-inertia axes using the environmental variables (origin of the arrows) and species (arrowheads) co-inertia weights ( $\mathrm{R}=$ rice-fields; $\mathrm{C}=$ channels; $\mathrm{S}=$ spring). The lower central plot indicates the environmental variables' weights, and the lower left plot shows the species scores. 
subject to quick variation of the hydrometric level and to total drainage (Ortmann-Ajkai and Kálmán, 2011); and H. lividus with a clear preference for waters with a low current velocity, high $\mathrm{pH}$, high conductivity with a luxurious vegetation, clay- and sand-substrate (Cuppen, 1986). In the present study, H. lividus ecology is emphasised as the species is plotted in the BCA in a separate area representing a rice field characterised by high $\mathrm{pH}$ and conductivity. The species $O$. albystilum, which results indicator in R3, probably cannot complete its cycle as it overwinters as larva and cannot find the condition for its development in a habitat which is dry in colder seasons. Once again it is important to notice that the result of statistical analysis must be used with caution, if it cannot be related to the autoecology of the species.

The SOM described differences in fauna composition with a lot of detail, adding information on the ecology of the different species in the habitat considered. It also emphasised that the presence of rare/endangered species allows to characterise some stations, but it is less informative about management strategies in rice paddies because most of these species are absent in rice fields.

The BCA pointed out the role of environmental variables in separating the habitats in the different stations, and their importance in allowing the colonisation by some species.

Some Chironomidae resulted to be good indicators of different habitats. This conclusion was supported by statistical analysis and was in agreement with the knowledge about the ecology of the species (Rossaro, 1982; Pillot, 2009). The IndVal analysis showed that $M$. pedellus preferred $\mathrm{S} 6$ and $C$. defectus $\mathrm{R} 5$, while the $\mathrm{BCA}$ revealed that O. fulva, Orthocladius excavatus Brundin, 1947, Paracladius conversus (Walker, 1856), M. pedellus and Harnischia fuscimanus Kieffer, 1921 preferred habitats with the lowest impact (R3, R4, C4, S6).

The present study confirmed the importance of different taxa of benthic macroinvertebrates in representing habitat quality in rice field wetlands. The different habitats chosen for the study, considered representative of Northern Italy rice agroecosystems, showed how these environments are very dynamic and complex, thus emphasising strict relations between benthic macroinvertebrates living in channels and rice fields. The period of water permanence in paddies resulted to be only one of the factors influencing the community of benthic macroinvertebrates, as evidenced in the analysis giving importance also to water chemical-physical parameters. These variables were influenced by human activities, but it is hard to separate the different sources of stress as they are strictly related. Although the natural ecosystem is in harmony with natural water quality, any significant changes in water will usually be disruptive to the ecosystem (Bartram and Balance, 1996).
However, as arthropods play an important role in the structure and maintenance of the ecosystems status, the high number of taxa found in the present research in few rice agroecosystems indicates that more information is required about the distribution and the status of macroinvertebrates in similar environments in Italy. Once more information on the communities is available, these results will also be valuable for having a more comprehensive view and found proper indicator species and indices of rice agroecosystem conservation status.

\section{ACKNOWLEDGMENTS}

This work was developed with a grant of University of Milan project: Unimi Per Il Futuro - 5 Per Mille: Evaluation of arthropod role in rice areas to maintain ecosystem equilibrium.

\section{REFERENCES}

Al-Shami, Che Salmah MR, Siti Azizah MN, Abu Hassan A, 2010. The influence of routine agricultural activities on the quality of water in a tropical rice field ecosystem. Appl. Ecol. Env. Res. 8:11-18.

Angelini R, Ferrero A, Ponti I, 2008. Il riso. Bayer Crop Scienc/Script ed., Bologna: 680 pp.

APHA, 2005. Standard methods for the examination of water and wastewater. $21^{\text {th }}$ ed., American Public Health Association, Washington, USA.

Bambaradeniya CNB, Edirisinghe JP, De Silva DN, Gunatilleke CVS, Ranawana KB, Wijekoon S, 2004. Biodiversity associated with an irrigated rice agro-ecosystem in Sri Lanka. Biodivers. Conserv. 13:1715-1753.

Barbone E, Rosati I, Reizopoulou S, Basset A, 2012. Linking classification boundaries to sources of natural variability in transitional waters: a case study of benthic macroinvertebrates. Ecol. Indic. 12:105-122.

Bartram J, Ballance R, 1996. Water quality monitoring - a practical guide to the design and implementation of freshwater quality studies and monitoring programmes. UNEP/WHO ed., Geneva: 348 pp.

Bazzanti M, Della Bella V, Seminara M, 2003. Factors affecting macroinvertebrate communities in astatic ponds in central Italy. J. Freshwater Ecol. 18:537-548.

Belfiore C, 1983. Efemerotteri (Ephemeroptera). 24. In: S. Ruffo (ed.), Guide per il riconoscimento delle specie animali delle acque interne italiane. CNR ed., Roma.

Bellini R, Pederzani F, Pilani R, Veronesi R, Maini S, 2000. Hydroglyphus pusillus (Fabricius) (Coleoptera: Dytiscidae): its role as a mosquito larvae predator in rice fields. Boll. Ist. Ent. G. Grandi Univ. Bologna 54:155-163.

Biggs J, Corfield A, Walker D, Whitfield M, Williams P, 1994. New approaches to the management of ponds. Br. Wildl. 5:273-287.

Borcard D, Gillet F, Legendre P, 2011. Numerical ecology with R. Springer, New York-Heidelberg: 301 pp.

Briers RA, Biggs J, 2003. Indicator taxa for the conservation of pond invertebrate diversity. Aquat. Conserv. 13:323-330.

Caldara M, Diotti L, Regalin R, 2004. Prima segnalazione per 
l'Europa di Lissorhoptrus oryzophilus Kuschel (Coleoptera, Curculionidae, Erirhinidae), temibile parassita di Oryza sativa L. Boll. Zool. Agr. Bachic. Ser. II 36:165-171.

Caramujo MJ, Boavida MJ, 2010. Biological diversity of copepods and cladocerans in Mediterranean temporary ponds under periods of contrasting rainfall. J. Limnol. 69:64-75.

Castagnolo L, Franchini D, Giusti F, 1980. Bivalvi (Bivalvia). 10. In: S. Ruffo (ed.), Guide per il riconoscimento delle specie animali delle acque interne italiane. CNR ed., Roma.

Cavazza F, 1914. Ricerche intorno alle specie dannose alla coltivazione del riso (Oryza sativa) e specialmente al Chironomus cavazzai Kieff. Boll. Lab. Zool. Gen. Agr. Portici 6:320-331.

Cham S, 2007. Field guide to the larvae and exuviae of British dragonflies. 1. British Dragonfly Society ed., Norfolk: $80 \mathrm{pp}$.

Cham S, 2009. Field guide to the larvae and exuviae of British dragonflies. 2. British Dragonfly Society ed., Norfolk: $76 \mathrm{pp}$.

Cocchi G, 1966. Ricerche sui Ditteri Chironomidi dannosi al riso nella bassa Bolognese. Boll. Oss. Mal. Piante Bologna 1: 39-64.

Confalonieri R, Mariani L, Bocchi S, 2005. Analysis and modelling of water and near water temperatures in flooded rice (Oryza sativa L.). Ecol. Model. 183:269-280.

Corbetta G, 1973. Damages to rice in Italy caused by Hydrellia griseola Fall. Bull. Inf. Rizic France 145:11-12.

Cuppen JGM, 1986. On the habitats distribution and life-cycle of the western European species of the genus Helochares Mulsant (Coleoptera: Hydrophilidae). Hydrobiologia 131:169-183.

de Jong YSDM, 2011. Fauna Europaea version 2.4. Accessed: 22/10/2012. Available from: http://www.faunaeur.org

Del Guercio, 1911. I Friganeidi nuocciono al riso. I tafani del riso. Le larve delle tipule nocive al riso. Redia 7:466-467.

Della Bella V, Bazzanti M, Chiarotti F, 2005. Macroinvertebrate diversity and conservation status of Mediterranean ponds in Italy: water permanence and mesohabitat influence. Aquat. Conserv. 15:583-600.

Dolédec S, Chessel D, 1994. Co-inertia analysis: an alternative method for studying species-environment relationships. Freshwater Biol. 31:277-294.

Dray S, Dufour AB, Chessel, D, 2007. The ade4 package-II: two-table and K-table methods. R News. 7:47-52.

Dussart GBJ, 1979. Life cycle and distribution of the aquatic gastropod molluscs Bithynia tentaculata (L.), Gyraulus albus (muller), Planorbis planorbis (L.) and Lymnea peregra (Muller) in relation to water chemistry. Hydrobiologia 67:223-239.

European Commission, 2006. Commission Decision of 20 November 2006 adapting Directives 73/239/EEC, 74/557/EEC and 2002/83/EC in the field of environment, by reason of the accession of Bulgaria and Romania, 2006/105/EC. In: Official Journal, 20/12/2006, pp 368-408. Accessed: 02/08/2012. Available from: http://eur-lex.europa.eu/LexUriServ/LexUriServ.do?uri=CELEX:32006L0105:EN:NOT

Fasola M, Villa M, Canova L, 2003. Le zone umide. Colonie di airone e biodiversità della pianura lombarda. Regione Lombardia e Provincia di Pavia ed., Pavia: 142 pp.

Ferrarese U, 1983. Chironomidi, 3 (Diptera, Chironomidae: Ta- nypodinae). 26. In: S. Ruffo (ed.). Guide per il riconoscimento delle specie animali delle acque interne italiane. CNR ed., Roma.

Ferrarese U, 1992. Chironomids of Italian rice fields. Neth. J. Aquatic. Ecol. 26:341-346.

Ferrarese U, Rossaro B, 1981. Chironomidi, 1 (Diptera, Chironomidae: generalià, Diamesinae, Prodiamesinae). 12. In: S. Ruffo (ed.), Guide per il riconoscimento delle specie animali delle acque interne italiane. CNR ed., Roma.

Friday LE, 1988. A key to the adults of British water beetles. Field Studies Council Publ., Shrewsbury: 152 pp.

Galli P, Crosa G, Mariniello L, Ortis M, D'Amelio S, 2001. Water quality as a determinant of the composition of fish parasite communities. Hydrobiologia 452:173-179.

Girod A, Bianchi I, Mariani M, 1980. Gasteropodi 1 (Gastropoda: Pulmonata; Prosobranchia: Neritidae, Viviparidae, Bithyniidae, Valvatidae). 7. In: S. Ruffo (ed.). Guide per il riconoscimento delle specie animali delle acque interne italiane. CNR ed., Roma.

Giusti F, Pezzoli E, 1980. Gasteropodi 2 (Gastropoda: Prosobranchia: Hydrobioidea, Pyrguloidea). 8. In: S. Ruffo (ed.). Guide per il riconoscimento delle specie animali delle acque interne italiane. CNR ed., Roma.

Goidanich A, 1939. Contributi alla conoscenza dell'entomofauna di risaia. 1. Gli Straziomidi: mancati nemici del riso. Risicoltura 29:221-230.

Heidemann H, Seidenbusch R, 2002. [Larves et exuvies des libellules de France et d'Allemagne (sauf de Corse)]. [Article in French]. Société française d'Odonatologie ed., Boys d'Arcy: 415 pp.

Higler LWG, Tolkamp HH, 1983. Hydropsychidae as bio-indicators. Environ. Monit. Assess. 3:331-341.

IUCN, 2012. IUCN red list of threatened species. Version 2012.1. Accessed: 02/08/2012. Available from: www.iucnredlist.org

Jucker C, Lupi D, 2011. Exotic insects in Italy: an overview on their environmental impact. In: J. Lopez Pujol (ed.), The importance of biological interactions in the study of biodiversity. InTech ed., Rijeka.

Kalyoncu H, Barlas M, Yildirim ZM, Yorulmaz B, 2008. Gastropods of two important streams of Gökova Bay (Mugla, Turkey) and their relationships with water quality. Int. J. Sci. Technol. 3:27-36.

Kohonen T, Hynninen J, Kangas J, Laaksonen J,1995. SOM_PAK. The Self-organizing Map. Program package. Helsinki University of Technology ed., Finland.

Lafont M, 1984. Oligochaete communities as biological descriptors of pollution in the fine sediments of rivers. Hydrobiologia 115:127-129.

Lawler SP, 2001. Rice fields as temporary wetlands: a review. Israel J. Zool. 47:513-528.

Legendre P, Legendre L, 2012. Numerical Ecology. Developments in Environmental Modelling. 24. Elsevier, Amsterdam: $990 \mathrm{pp}$.

Leitão S, Pinto P, Pereira T, Brito MF, 2007. Spatial and temporal variability af macroinvertebrate communities in two farmed Mediterranean rice fields. Aquat. Ecol. 41:373-386.

Lek S, Guegan JF, 2000. Artificial neuronal networks: application to ecology and evolution. Springer, Berlin: $262 \mathrm{pp}$.

Lencioni V, Maiolini B, Marziali L, Lek S, Rossaro B, 2007. Macro-invertebrate assemblages in glacial stream systems: 
a comparison of linear multivariate methods with artificial neural networks. Ecol. Model. 203:119-131.

Maroneze DM, Tupinambas TH, Franca JS, Callisto M, 2011. Effects of flow reduction and spillways on the composition and structure of benthic macroinvertebrate communities in a Brazilian river reach. Braz. J. Biol. 71:639-651.

Martins RT, Stephan NNC, Alves RG, 2008. Tubificidae (Annelida: Oligochaeta) as an indicator of water quality in an urban stream in southeast Brazil. Acta Limnol. Bras. 20:221226.

Menetrey N, Oertli B, Sartori M, Wagner A, Lachavanne JB, 2008. Eutrophication: are mayflies (Ephemeroptera) good bioindicators for ponds? Hydrobiologia 597:125-135.

Minelli A (ed.), 2001. Risorgive e fontanili, acque sorgenti di pianura dell' Italia settentrionale. Quaderni Habitat. Ministero dell'Ambiente e della Tutela del Territorio. Museo Friulano di Storia Naturale ed., Udine: 155 pp.

Moller Pillot HKM, 2009. Chironomidae Larvae. Biology and ecology of the Chironomini. KNNV Publ., Zeist: 249 pp.

Moormann FR, van Breemen N, 1978. Rice: soil, water, land. International Rice Research Institute Publ., Los Baños: 185 pp.

Moretti GP, 1932. Note sulla fauna entomologica delle risaie. Atti Soc. Ital. Sci. Nat. 71:61-85.

Moretti GP, 1934. I tricotteri delle risaie. Atti Soc. Ital. Sci. Nat. 73:104-116.

Moretti GP, 1983. Tricotteri (Trichoptera). 19. In: S. Ruffo (ed.), Guide per il riconoscimento delle specie animali delle acque interne italiane. CNR ed., Roma: 155 pp.

Moroni A, 1961. L'ecosistema di risaia. Ann. Fac. Agraria di Piacenza 3:489-625.

Nocentini A, 1985. Chironomidi, 4 (Diptera, Chironomidae: Chironominae, larve). 29. In: S. Ruffo (ed.), Guide per il riconoscimento delle specie animali delle acque interne italiane. CNR ed., Roma: 186 pp.

Olmi M, 1978. Driopidi, elmintidi (Coleoptera Dryopidae, Elminthidae). 2. In: S. Ruffo (ed.), Guide per il riconoscimento delle specie animali delle acque interne italiane. CNR ed., Roma: $71 \mathrm{pp}$.

Ortmann-Ajkai A, Kálmán Z, 2011. Aquatic beetle and bug assemblages of standing waters with different successional stages in the floodplain of Drava. Acta Biol. Debr. Oecol. Hung. 26:161-178.

Panizzon JP, Macedo VR, Machado V, Fiuza LM, (2012). Microbiological and physical-chemical water quality of the rice fields in Sinos River's basin, Southern Brazil. Environ. Monit. Assess. (in press).

Pasini M, Ferrarese U, 1998. I Chironomidi delle risaie dell'Italia Nord-orientale: chiavi per il riconoscimento. Boll. Zool. Agr. Bachic. Ser. II 30:79-114.

Pinna M, 1978. L'atmosfera e il clima. Utet, Torino: 478 pp.

Pirisinu Q, 1981. Palpicorni (Coleoptera: Hydraenidae, Helophoridae, Spercheidae, Hydrochidae, Hydrophilidae, Sphaeridiidae). 13. In: S. Ruffo (ed.), Guide per il riconoscimento delle specie animali delle acque interne italiane. CNR ed., Roma: 96 pp.

Podani J, Csànyi B, 2010. Detecting indicator species: some extensions of the IndVal measure. Ecol. Indic. 10:1119-1124.

Rossaro B, 1982. Chironomidi, 2 (Diptera, Chironomidae: Orthocladiinae). 16. In: S. Ruffo (ed.), Guide per il riconoscimento delle specie animali delle acque interne italiane. CNR ed., Roma: 80 pp.

Rossi V, Benassi G, Veneri N, Bellavere C, Menozzi P, Moroni A, McKenzie KG, 2003. Ostracoda of the Italian rice fields thirty years on: new syntesis and hypothesis. J. Limnol. $62: 1-8$.

Ruffo S, Stoch F, 2005. Checklist e distribuzione della fauna italiana: 10.000 specie terrestri e delle acque interne. Museo civico di storia naturale di Verona ed., Verona: 307 pp.

Smith ND, Golladay SW, 2011. Coleoptera indicator species in wet vs. dry climate regimes in three southwestern Georgia wetland types. In: Proc. of Georgia Water Resource Conference, Athens, USA. Available from: http://www.gwri.gatech.edu/sites/default/files/files/docs/2011/4.2.4Smith.pdf

Stoch F (ed.), 2005. Pools, ponds and marshes small water bodies, oases of biodiversity. Museo Friulano di Storia Naturale ed., Udine: 158 pp.

Suhling F, Befeld S, Häusler M, Katzur K, Lepkojus S, Mesleard F, 2000. Effects of insecticide applications on macroinvertebrate density and biomass in rice-fields in the Rhône-delta, France. Hydrobiologia 431:69-79.

Supino F. 1916. Osservazioni sopra alcuni insetti delle risaie. Reale Istituto Lombardo di Scienze e Lettere. 49:108-114.

Supino F. 1932. Note sulla fauna delle risaie. Reale Istituto Lombardo di Scienze e Lettere. 54:1-12.

Tamanini L, 1979. Eterotteri acquatici (Heteroptera: Gerromorpha, Nepomorpha). 6. In: S. Ruffo (ed.), Guide per il riconoscimento delle specie animali delle acque interne italiane. CNR ed., Roma: 106 pp.

Timm T, 1999. A guide to Estonian Annelida. Estonian Academy Publishers, Tallinn: 207 pp.

Vesanto J, Himberg J, Alhoniemi E, Parhankangas J, 1999. Selforganizing map in Matlab: the SOM Toolbox, p. 35-40. In: Proc. of the Matlab DSP Conference 1999, Espoo, Finland.

Viera NKM, Clements WH, Guevara LS, 2004. Resistance and resilience of stream insect communities to repeated hydrologic disturbances after a wildfire. Freshwater Biol. 49:1243-1259.

Wiederholm T, 1983. Chironomidae of the Holoarctic region. Keys and diagnoses. 1. Larvae. Entomol. Scand. Supplement 19:1-457.

Wiederholm T, 1986. Chironomidae of the Holoarctic region. Keys and diagnoses. 2. Pupae. Entomol. Scand. Supplement 28:1-482.

Wiederholm T, 1989. Chironomidae of the Holoarctic region. Keys and diagnoses. 3. Adult males. Entomol. Scand. Supplement 34:1-532.

Zangheri S, 1956. Un dittero minatore del riso nel basso ferrarese. (Hydrellia griseola Fallen, Dipt. Ephydridae). Boll. Soc. Entomol. Ital. 86:12-16. 